\title{
FEATURES OF ISLAMIC STATE AND POLITICS
}

\author{
INAM ULLAH WATTOO \\ Ph.D. Scholar, Department of Islamic Studies, \\ The Islamia University of Bahawalpur, Pakistan \\ Email: Inamullahwattu009@gmail.com
}

\begin{abstract}
Islam is a universal religion and final version of past divine religions. It provides guidance in every sphere of human life. It is the duty of religion to establish a peaceful existence in society. Now a days western and European countries (under modern and western political system) are facing a serious issue of pluralism. They are trying their best to solve it but all in vain. Islam presents a unique political system which is the only solution of such problems. Islamic political system provides peaceful coexistence for pluralistic society. Examples of the period of pious Caliphs is a great evidence in this concern. There are three types of Islamic government, namely Immamat, Immarat, and Khalafat. Furthermore there are three types of Khilafat; general, individual and national Caliphate. Islam provides very clear instructions for the selection of a caliph. Head of Islamic state should be a Muslim. According to Sharia, firm belief on the oneness of Allah and finality of Prophethood in the Prophecy of Hazrat Muhammad (PBUH) are basic conditions for being a Caliph in an Islamic state. In this political system Allah is the only sovereign of the state. It is the duty of all Muslims to obey Allah, his apostle and ruler of the time. All the matters of the state are discussed in Majlas e Shura. Ruler of the state is answerable before his subjects and Allah almighty. In Islam, politics and religion are not different departments. This article deals with the functions and feature of the Islamic state.
\end{abstract}

Keywords: Immamat, Khilafat, Immarat, Muhajareen,Majis Shura, Aws, khazraj, Saqeefa bani Saada

\section{INTRODUCTION}

It is the authenticity of Islamic teachings, that it guide the followers in every field of life. Hazrat Muhammad (PBUH) was appointed not only to teach but he showed practical implementation of Islamic teachings. It is Muslim belief, that the Islam is a universal religion with universal teachings. All the previous religions were not universal, so their teachings were concern to specific period or nation. Being universal religion of the world, Islam deliver universal moralities and teachings. Hazrat Muhammad (PBUH) was not only a 
prophet but a leader of the society. He (PBUH) led his life in a society and left many example for the guidance. Writers of Prophetic biography, highlights Him as a Leader, Trader, Justice, Teacher, Father and Husband etc. so we can find guidance for every field of life in his teachings and practical life. It is very clear that it is the religion which provide guidance for living in a society in peaceful co-existence. The pluralism is the most important issue of modern era. All the western thinkers are working on this issue. They conduct seminars, conferences, delivered lectures, publishing papers and books, in spite of these struggles they did not sort out any suitable solution for this issue. As now in modern ear, Muslims and non-Muslims are living together in a state, especially in non-Muslim governed states. There are different religions with different theologies which cause uneasiness among the people of society.

Islam have its own political philosophy, in which Allah almighty is the sovereign power of the state, Hazrat Muhammad (PBUH) was a prophet and Caliph of Allah on the earth. In the period of prophet-hood Islam developed its political philosophy with the guidance of Allah and prophetic traditions and these were saved as examples of implementation. Later the Pious Caliph, practically implemented the political philosophy of Islam and enhance the Islamic state and rule. Islam being a final version of all the previous religions provides the guidance for all aspects of life. It did not narrate any new order for life, but consist on those ethical values which were narrated by the past religions. So we can say that Islam is a final version of the previous religions. Following verses of the Holy Quran approved the authenticity of this statement:

"We did not send before you any messenger but we revealed to him that there is no god but I, so worship Me."

All the previous prophets were appointed for the same purpose:

"Surely, We have revealed to you as We have revealed to $\mathrm{NuH}$ and to the prophets after him; and We have revealed to Ibrahim, Ismai'l, IsHaq, Ya'qub and their children, and to Isa,. Ayyub, Yunus, Harun and Sulaiman, and We have given Zabur to Dawud. (We have sent) some Messengers We have already told you about, and some other Messengers We did not tell you about, and Allah has spoken to Musa verbally. - Messengers giving good tidings and warning, so that people may have no plea against Allah after the Messengers (have come). Allah is All-Mighty, All-Wise. "ii

Religion plays an important role in human life. It provides collective code of life. Writer of Wikipedia define the religion in these words: 
"A religion is an organized approach to human spirituality which usually encompasses a set of narratives, symbols, beliefs and practices, often with a supernatural or transcendent quality, that give meaning to the practitioner's experiences of life through reference to a higher power or truth. It may be expressed through prayer, ritual, mediation, music and art, among other things."

It is very clear that it is the religion which provide guidance for living in a society in peaceful co-existence. The pluralism is the most important issue of modern era. All the western thinkers are working on this issue. They conduct seminars, conferences, delivered lectures, publishing papers and books, in spite of these struggles they did not sort out any suitable solution for this issue. As now in modern ear, Muslims and non-Muslims are living together in a state, especially in non-Muslim governed states. There are different religions with different theologies which cause uneasiness among the people of society. Islam have its own political philosophy, in which Allah almighty is the sovereign power of the state, Hazrat Muhammad (PBUH) was a prophet and Caliph of Allah on the earth. In the period of prophet-hood Islam developed its political philosophy with the guidance of Allah and prophetic traditions and these were saved as examples of implementation. Later the Pious Caliph, practically implemented the political philosophy of Islam and enhance the Islamic state and rule.

\section{TYPES OF ISLAMIC GOVERNMENT}

There are three terminologies used for Islamic system of government. Immamat, (Leadership) Khilafat (Caliphate), and Immarat (guidance).

\section{A. IMMAMAT}

It is a leadership of democratic government which gained its authoritative superiority through the legal representation of the Holy Prophet Hazrat Muhammad (PBUH). It shows its power and greatness in the collective activities of religion and daily life in the way that appear its qualities of superior guidance.

\section{B. CALIPHATE}

According to the Holy Quran there are three kinds of Caliphate; General Caliphate, national Caliphate and individual Caliphate. 


\section{COMMON CALIPHATE}

All human beings are the vice-regent of Allah and were born to rule on the rest of creations.

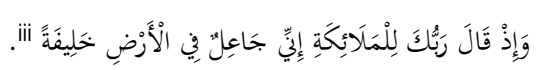

In this verase Allah almighty called the all human being his Caliph.

\section{NATIONAL CALIPHATE}

When a nation is blessed with government it called national Caliphate. As Allah almighty addressed the nation of Prophet Aad in these words:

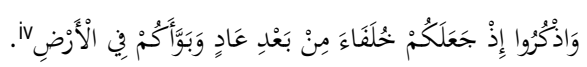

\section{E. INDIVIDUAL CALIPHATE}

There are two types of individual Caliphate; Special individual Caliphate and general individual Caliphate. When Allah almighty appoint someone to guide the humanity it called special individual Caliphate. All the messengers and Prophets are categorized as special individual caliphate.

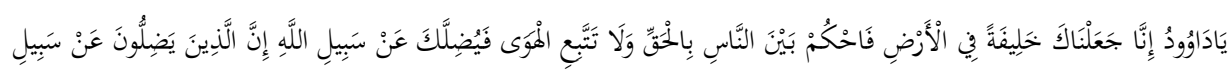

$$
\begin{aligned}
& \text { اللَّه. }
\end{aligned}
$$

General individual Caliphate mean a ruler of the state appointed after the death of a Caliph.

\section{QUALITIES OF ISLAMIC CALIPHATE}

Qualities of Islamic Caliphate are given here. The first quality of Islamic Caliphate which distinguished it from other political system, is the combination of State and religion. Second quality of Islamic Caliphate is to make compulsory of Allah's obedience. If there is un-obedience of Allah it could not be called Caliphate. Third quality of Islamic Caliphate is the sovereignty of Allah almighty. Fourth major quality of Islamic caliphate is that it order for the good deeds and forbid the evils.

"Ruler in subject is like a spirit in a body"

\section{A. SELECTION OF A CALIPH}

Leader of the state should be selected with the consultancy of its subject. 


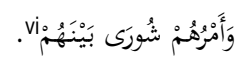

In the beginning period of Islam selection of pious caliph was through consultation. First Caliph Hazrat Abu bakar Sadiq (R.A) was selected through direct consultation. Oath of his Caliphate was took place in Saqeefa bani Saada, where all the men of opinion from Muhajareen (Makkan) and Anasr (Madinian) were present. There was a long discussion for the selection of a Caliph, reasons of priority for Caliph were discussed. At last all agreed on the selection of Hazrat Abu bakar Sadiq (R.A). Second Caliph Hazrat Umar (R.A) was nominated by the first Caliph with the consultancy of Majalas-e-Shoura. After it was present to public for general opinion. So He was not nominated only with the will of Hazrat Abu bakar Sadiq (R.A) but it was publically consulted and accepted. Hazrat Umar (R.A) organized a committee for the selection of his successor Caliph, and it was directed to choose a Caliph with the consultation of people.in this way Hazrat Ali (R.A) was also selected with the opinion and will of general subject.

\section{B. ELIGIBILITY CRITERIA FOR CALIPH}

Head of Islamic state should be a Muslim. According to Sharia, firm belief on the oneness of Allah and finality of Prophet Hood in the Prophecy of Hazrat Muhammad (PBUH) are basic conditions for being a Caliph in an Islamic state.

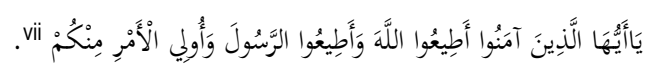

Word بـ clearly indicates that the ruler of Muslim community should be among the Muslims. Second condition for Caliph is wisdom and maturity in age. Third, he should not be physically disable. Fourth, he should be well aware about the current political requirements.

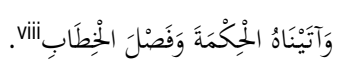

Fifth, he should be a theologian, it is compulsory for the Caliph to be expert in religious knowledge. So that he may solve the problems in the light of Islamic teachings and could not ignore the limits of Sharia because of his ignorance. Sixth, he should be pious, just and trustful. The Holy Quran stated:

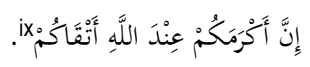

"Surely the noblest of you, in Allah's sight, is the one who is most pious of you."

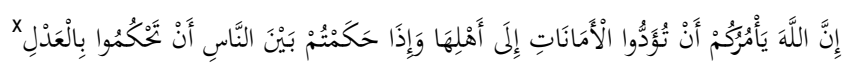


"Surely, Allah commands you to deliver trusts to those entitled to them, and that, when you judge between people, judge with justice."

Seventh, braveness is a compulsory condition for being a Caliph of Islamic State. So that at the time of foreign attack he may wage a war and inspire the people for Jihad.

Last condition for the Caliph of Islamic state is to be a Male.

\section{ISLAMIC CONCEPT OF SOVEREIGNTY}

Theory of sovereignty is one of the most important political theory of the Holy Quran. According to Quranic theory sovereignty is not hand over to human as man is not enough powerful but he is very week and frequently forget his duties. Allah is the only and alone who deserve to be the power of Sovereignty. For sovereignty the Holy Quran used the word ملكوت. By which it is explained that all the things and matters of the whole world are under the control of Allah Almighty.

"Who is the One in whose hand lies the kingdom of everything?"xi

The Holy Quran uses different terminologies for the sovereignty of God:

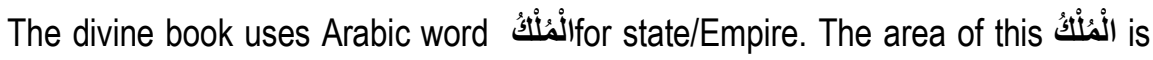
not limited to the area of earth only but it include the whole universe, and all the things which exist between the earth and heavens.

"To Allah belongs the East and the West."xii

"Unto Allah belongs the kingdom of the heavens and the earth."xiil

"Glorious is the One to whom belongs the kingdom of the heavens and the earth and whatever lies between them. "xiv

"(No,) because to Allah alone belongs the (good of) the Hereafter and the former life (of this world). ${ }^{3} \mathrm{x}$

\section{OBEDIENCE OF CALIPH OR HEAD OF STATE}

"O you who believe! Obey God and obey the Prophet and those of you who hold authority"xvi.

Saying Ascribe to the Prophet:

"I charge the Caliph after me to fear God, and I commend the community of the Muslim to him, to respect the great among them and have pity on the small, to honor the learned among them, not to strike them and humiliate them, not to oppress them and drive them to unbelief, not to close his doors to them and allow the strong to devour the weak. "xvii 


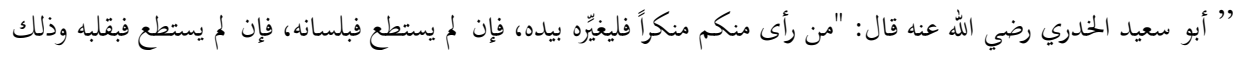

$$
\begin{aligned}
& \text { أضعف الإيمان xviii }
\end{aligned}
$$

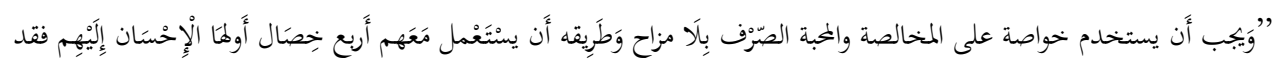

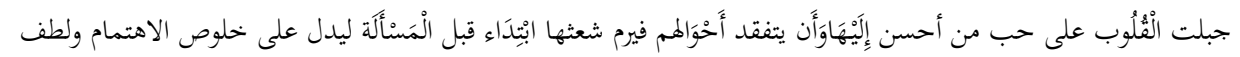

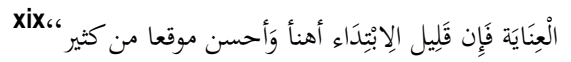

\section{POLITICAL ASPECTS OF ISLAM}

Discussing the political system of Islam a western writer cited a famous Muslim scholar (Abu Hamid al-Ghazali) in his book "Faith and Force: The political issues of Islam."

"Political aspects of Islam are derived from the Qur'an, the Sunna (the sayings and living habits of Muhammad), Muslim history, and elements of political movements outside Islam. Traditional political concepts in Islam include leadership by elected or selected successors to the Prophet known as Caliphs, (Imamate for Shia); the importance of following Islamic law or Sharia; the duty of rulers to seek Shura or consultation from their subjects; and the importance of rebuking unjust rulers. "xx

"A significant change in the Islamic world was the abolition of the Ottoman caliphate in 1924." $x x i$

In the nineteenth and twentieth century, normal Islamic political subject has been imperviousness to Western government and requirement of Sharia through just or aggressor battle. The annihilation of Middle Easterner armed forces in the Six Day War, the end of Cool War and breakdown of the Soviet Union with the end of socialism as a suitable option has expanded the bid of Islamic developments, for example, Islamism, Islamic fundamentalism and Islamic majority rules system, particularly in the setting of famous disappointment with secularist administering administrations in the Muslim world.

\section{A. ISLAM AS A POLITICAL MOVEMENT}

Political thoughts of Islam based on the ruling practice of Hazrat Muhammad (PBUH) and pious Caliph. In $622 \mathrm{CE}$, Hazrat Muhammad (PBUH) laid the foundations of first Islamic state in Yathrib. There he solved the disputes among dominant local tribes of Arab, in this way $\mathrm{He}$ (PBUH) proved his wisdom and ability to rule over the territory. After this He (PBUH) drafted the charter of Madina. This charter is based on revelations and traditions of the Holy Prophet Hazrat Muhammad (PBUH). This charter is considered sharia or Islamic legal code for Muslims. Even now in recent period Islamic organizations follow this document as enlighten. Within a short period the Holy Prophet Hazrat Muhammad 
(PBUH) gained a huge number of followers and his rule extended first in the Makkah and then to the whole Arab peninsula through diplomacy and military innovations.

Now in Muslim majority states democratic parties are existing. Various groups of Muslim militants are effectively operating in particular parts of world. The flawed term Islamic fundamentalism has moreover been sired by some non-Muslims to depict the political and religious strategies for knowledge of some Muslim militant organizations. Both of these terms Islamic democracy and Islamic fundamentalism hitch together a broad variety of social affairs with fluctuating histories, theories and associations.

\section{B. MEDINA AS AN ISLAMIC STATE}

The constitution of First Islamic state was drafted by the prophet Hazrat Muhammad (PBUH). It constituted a formal understanding between Hazrat Muhammad (PBUH) and the majority of the critical tribes and groups of Yathrib, including Muslim, Jews, Christians and Agnostics. This constitution shaped the foundation of first Islamic realm.

"The document was drawn up with the explicit concern of bringing to an end the bitter inter-tribal fighting between the clans of the Aws (Aus) and Khazraj within Medina. To this effect it instituted a number of rights and responsibilities for the Muslim, Jewish, Christian and Pagan communities of Medina bringing them within the fold of one communitythe Ummah." xxii

"The exact dating of the Constitution of Medina stays faced off regarding however for the most part researchers concur it was composed soon after the Hijraa. "xxiii

After death of Hazrat Muhammad (PBUH), His group expected to designate another pioneer, offering ascent to the title Caliph, and signifying "successor". In this way the ensuing Islamic realms were known as Caliphates. Nearby the development of the Umayyad domain, the major political improvement inside Islam in this period was the partisan split among Sunni and Shiite Muslims; this had its roots in a disagreement about the progression of Caliphate.

"Sunni Muslims trusted the caliphate was elective, and any Muslim may serve as one. Shiites, then again, trusted the caliphate ought to be genetic in the Prophet's line, and in this manner every one of the caliphs, except for Ali, were usurpers. "xxiv

The Sunni order developed as triumphant in a large portion of the Muslim world, and subsequently most recent Islamic political developments are established in Sunni thought. 
"Nearest companions of Hazrat Muhammad (PBUH) and four pioneer Caliphs who succeeded him, kept on growing the state to envelop Jerusalem, Ctesiphon, and Damascus, and sending armed forces similarly toward the Sindh." $x \times v$

The Islamic realm extended from Muslim Spain to Punjab under the rule of the Umayyad. The overcoming Arab armed forces applied Sharia laws and courts to their new military camps and urban communities, and assembled mosques for Friday prayer and in addition Madrasahs to instruct Muslim youth. These foundations brought about the improvement of a class of scholars who could serve as judges, imams of mosques and madrasah instructors.

\section{ELECTION OR APPOINTMENT}

The ideas of radicalism and democracy were already exist in the medieval Islamic world. Period of pious Caliphate was an early example of a democratic state however it was stopped after Sunni-Shia split. Western researcher of Islam, contends that the standard Arabian precedents on amid the early Caliphates was for the prominent persons of a tribe, to accumulate after a pioneer's passing and choose a pioneer from amongst them, in spite of the fact that there was no predetermined strategy for this Consultative assembly. Competitors were for the most part from the same heredity as the expired pioneer however they were not so much his children.

"Competent men who might lead well were favored over an incapable direct beneficiary, as there was no premise in the greater part Sunni view that the head of state or representative ought to be picked in light of ancestry alone. "xxvi

\section{A. CONSULTATIVE ASSEMBLY OR MAJLIS ASH-SHURA}

An essential Islamic idea concerning the structure of decision is shura, or discussion with individuals in regards to their undertakings. The obligation of rulers said in the Quran:

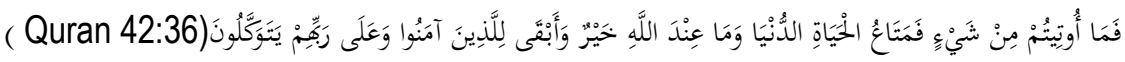

"In the perspective of modern political thoughts Pious Caliphate was not democratic as decision making force lay with a committee of eminent and trusted colleagues of Hazrat Mohammad (PBUH) and agents of diverse tribes."xxvii 
Customary Sunni Islamic legal advisors concur that shura, inexactly interpreted as "opinion of the general population", and is an element of caliphate. The Majlis Shura prompts the ruler.

"Those who answer the call of their Lord and establish the prayer, and who conduct their affairs by Shura." xxviii

"Consult them (the people) in their affairs. Then when you have taken a decision (from them), put your trust in Allah". xxix

The Shura is likewise intends to choose another caliph. According to a Muslim Jurist the individuals from the males ought to fulfil three conditions: they must be just, they must have enough information to recognize a decent caliph from a terrible one, and must have adequate shrewdness and judgment to choose the appropriate man for Caliphate.

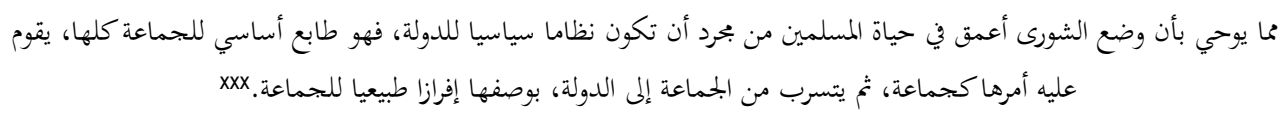

Notwithstanding, these understandings of Shura are not all around acknowledged and Islamic democrats consider Shura to be an indispensable part and essential mainstay of Islamic political framework. Non-Muslims may serve as individuals from majlis (gathering) of Shura, however they can't get to be possibility for position of head of Islamic state.

\section{B. RELIGION AND POLITICS}

Not at all like Christianity, Islam does not isolate religion from state, and numerous Muslims contend it is opinionated Islam not political Islam that obliges clarification and that is an authentic fluke of the "short-lived prime of mainstream Arab patriotism somewhere around 1945 and 1970. In the early Islamic Caliphate, the head of state, the Caliph, had a position of a successor to Hazrat Muhammad (PBUH's) political power, who, as per Sunnis, were in a perfect world chose by the general population or their agents. Similar to the case for the decision of Abu Bakar, Uthman and Ali as Caliph. After the Rashidun Caliphs, later Caliphates amid the Islamic Golden Age had a much lesser level of majority rule support, yet since "nobody was better than any other person aside from on the premise of devotion and prudence" in Islam, and taking after the sample of Hazrat Muhammad (PBUH), later Islamic rulers frequently held open discussion with the general population in their issues.

"The state was instrument to empower Muslims to live as great Muslims and Muslims were to comply with the sultan on the off chance that he did as such. The ruler's authenticity was "symbolized by the privilege to coin 
cash and to have the Friday petition to God (Jumu'ah khutba) said in his name. "xxxi

\section{ACCOUNTABILITY}

"And they (the sinners on qiyama) will say, 'Our Lord! We obeyed our leaders and our chiefs, and they misled us from the right path. Our Lord! Give them (the leaders) double the punishment you give us and curse them with a very great curse'. "xxxii

If the rulers meet their Islamic obligations to general society, the general population must comply with their laws, however in the event that they turn out to be either shameful or extremely insufficient then the Caliph or ruler must be reprimanded by means of the Majlis-e-Shura. If the rulers don't maintain equity, the ummah by means of the majlis ought to offer cautioning to them, and if unnoticed then the Caliph can be indicted. Islam is the objective of the ummah, so any ruler that goes astray from this objective must be denounced. Persecution by a caliph is sufficient for indictment. Instead of simply depending on indictment. Insubordination is obliged upon the general population if the ruler started to violate sharia. To disregard such a circumstance is haraam, and the individuals who can't revolt inside the caliphate ought to dispatch a battle from outside. Some Muslim jurists utilized this verse from the Quran to legitimize this:

"Islamic legal counselors remarked that when the rulers decline to venture down by means of effective reprimand through the Majlis, getting to be tyrants through the backing of a degenerate armed force, if the larger part concur they have the alternative to dispatch an unrest against them. Numerous prominent that this alternative is just practiced subsequent to considering in the potential expense of life. "xxxiii

\section{UULAA AL-AMR}

"O believers! Obey God and obey the Apostle and those who have been given authority [uulaa al-amr] among you. "xxxiv

For Sunnis, Uulaa al-amr are the rulers (Caliphs and lords) yet for Shiis this expression alludes to the Imams. This Quranic verse has been expounded in various colloquialisms credited to Hazrat Muhammad (PBUH). In any case, there are likewise adages that put strict points of confinement on the obligation of dutifulness. Two dicta credited to the Prophet and generally acknowledged as real are demonstrative. One says, "There is no acquiescence in sin"; if the ruler issued something in opposition to the heavenly law arrives no obligation of compliance, as well as there is an obligation of noncompliance. 
"The "worldview of the official as a power unchecked by either the jurists of sharia or the prevalent power of a chose assembly turned into the predominant worldview in a large portion of the Sunni Muslim world in the twentieth century. "xxxv

\section{CONCLUSION}

Islam is the only religion in the world which provide accurate solution for the said issue. There are many historical evidence that the first Islamic state Medina, was built up by the Prophet Hazrat Muhammad (PBUH). The subject of the state was of different religions, as Jews, Christians, and Pagans etc. It was first time in mankind's history that the people of different religions were living peacefully with each other's. Hazrat Muhammad (PBUH) signed a contract with them. According to which all the subject of the state was equal. They were free to practice on their religion. There was no discrimination among them on the base of religion, creed and cast. They were in contract to assist each other's for collective benefits, like in a case of foreign attack on the state but they were not permitted to hurt each other in their religious matters.

$\mathrm{He}(\mathrm{PBUH})$ was the first head of Islamic state Medina. This was the first state of human history which guaranteed the rights of all human kind. Being a state man $\mathrm{He}$ (PBUH) conduct wars with enemies, arrange contracts with other nations, resolve Political and social issues of the society.

\section{REFERENCES}

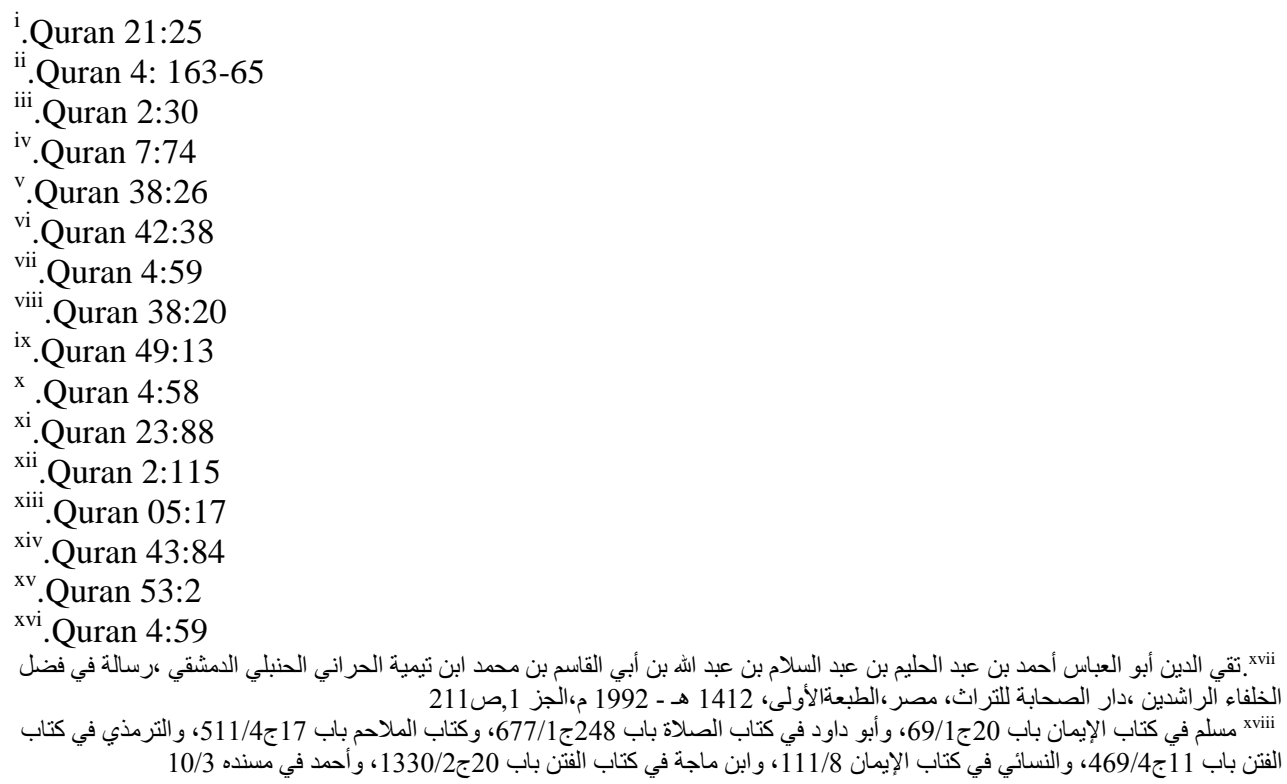


Pakistan Journal of Humanities and Social Sciences, 4(2), 2016

xix الحسين بن علي بن الحسين، أبو القاسم الوزير المغربي ،رسالة ضمن (مجموع في السياسة)، مؤسسة شباب الجامعة - الإسكندرية،ص23

${ }^{x x}$. Mortimer, Edward, Faith and Power: The Politics of Islam, ( Abu Hamid al-Ghazali quoted) Vintage Books, 1982 , p.37

xxi. Feldman, Noah, Fall and Rise of the Islamic State, Princeton University Press, 2008, page\#2

${ }^{x x i i}$.R. B. Serjeant, The Sunnah Jâmi'ah, Pacts with the Yathrib Jews,. Ed. Uri Rubin. Brookfield: Ashgate, 1998, page\# 4.

xxiii. Watt. Montgomery, Muhammad at Medina. Oxford University Press, 1989 Page\# 227-228,

xxiv.Lewis, Bernard, The Middle East : a Brief History of the last 2000 Years, Touchstone, 1995, page\#139

xxv.Mortimer, Edward, Faith and Power: The Politics of Islam, Vintage Books, 1982, page\#.37

${ }^{x x v i}$.Fred Donner, The Early Islamic Conquests, Princeton Univ Press, 1981,page \#221

xxvii. Sohaib N. Sultan, Forming an Islamic Democracy, http://www.arabphilosophers.com/English/discourse/ arabic/Political_Philosophy/Formin_Islamic_Democracy.htm

xxviii .Quran 42:38

${ }^{x x i x}$.Quran 3:159

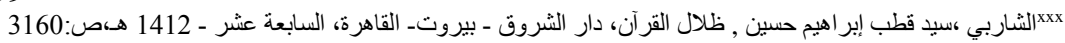
xxxi.Roy, Olivier, The Failure of Political Islam, translated by Carol Volk, Harvard University Press, 1994, page\#14-15

xxxii.(Quran 33:67-68)

xxxiii. Process of Choosing the Leader (Caliph) of the Muslims: The Muslim Khilafa, page\# 21

xxxiv.(Quran 4:59)

${ }^{x x x v}$.Feldman, Noah, Fall and Rise of the Islamic State, Princeton University Press, 2008, page\#79 